\title{
Growth Analysis of Sourgrass: Does Herbicide Resistance Affect Its Development?
}

\author{
Fernando Storniolo Adegas ${ }^{1}$, Dionísio Luiz Pisa Gazziero ${ }^{1}$, Alexandre Ferreira da Silva ${ }^{2} \&$ Germani Concenço $^{3}$ \\ ${ }^{1}$ Embrapa Soja, Londrina, Paraná, Brazil \\ ${ }^{2}$ Embrapa Milho e Sorgo, Sete Lagoas, Minas Gerais, Brazil \\ ${ }^{3}$ Embrapa Clima Temperado, Pelotas, Rio Grande do Sul, Brazil \\ Correspondence: Alexandre Ferreira da Silva, Embrapa Milho e Sorgo, Sete Lagoas, Minas Gerais, 35700-910, \\ Brazil. Tel: 55-31-3027-1251. E-mail: alexandre.ferreira@embrapa.br
}

\author{
Received: April 3, $2019 \quad$ Accepted: May 27, $2019 \quad$ Online Published: July 31, 2019 \\ doi:10.5539/jas.v11n11p214 URL: https://doi.org/10.5539/jas.v11n11p214
}

\begin{abstract}
Sourgrass (Digitaria insularis) is highlighted as one of the most troublesome weeds in Brazilian agriculture. The growth analysis of the species and biotypes with resistance to glyphosate are preponderant to support management strategies. In this way, the aim of this work is to compare the growth of biotypes resistant and susceptible to glyphosate, and to characterize the species growth in field conditions. The greenhouse experiment was installed in randomized blocks design, in factorial scheme $2 \times 10$, with eight replications. Factor A comprised the biotypes, and factor B the fortnight evaluations. The dry mass of roots, stems, leaves and shoot were assessed, besides leaf area and plant height. From these variables, the relative growth rate, net assimilation rate and leaf area ratio were calculated. For the field experiment, the same variables were assessed and the same parameters were calculated, without distinction on resistant or susceptible biotype. The biotype with resistance to glyphosate did not show adaptative disadvantages compared to the susceptible one. In this way, it is necessary to prevent the entry of resistant biotypes in cropped fields, as once established the area may not naturally return to the initial frequency of susceptible biotypes. Sourgrass shown slow initial growth and dry mass accumulation up to 42 days after emergence, indicating that control of this specie should be performed preferably before this period.
\end{abstract}

Keywords: Digitaria insularis, fitness cost, glyphosate resistant

\section{Introduction}

Sourgrass (Digitaria insularis) is characterized by being perennial, erect, reproduced by seeds and rhizomes, and adapted to germinate under broad climatic conditions (Gemelli et al., 2012; Mendonça, C. Martins, D. Martins, \& Costa, 2014). Nowadays, it stands out as one of the most problematic weeds in tropical Brazilian agriculture. The wide dissemination of glyphosate-resistant biotypes in the main grain-producing regions, associated with the difficulty to control perennialized plants, make its management a great challenge for farmers (Lopez-Ovejero et al., 2017; Gilo, Mendonça, Santo, \& Teodoro, 2016). Studies evaluating the biological/ecological behavior of this species are of great importance to better understand its dynamics in the environment; thus, help in the elaboration of effective management strategies.

The analysis of weed growth parameters is an important component in the evaluation of their ability to interfere on crop growth, as it is directly correlated to competitive ability. In addition, in perennial and rhizomatous plants such as sourgrass, knowing its growth rate may help in determining the best period for control. After the formation of rhizomes, the control levels following glyphosate application tends to decrease probably due to the accumulation of starch, which tend to reduce herbicide translocation to growth points (Machado et al., 2008). Studies were conducted to characterize the growth of sourgrass (Marques et al., 2013, 2014; Machado et al., 2006). However, there is no study contrasting these results with those observed under field conditions.

Plant development is affected by a set of biotic and abiotic factors. It is believed that the limitation of space in the pots used as experimental plots in greenhouse conditions may underestimate plant's growth capacity, especially in the formation of rhizomes. Thus, studies evaluating sourgrass growth in different field conditions should be contrasted with data observed in controlled environments. 
In addition to a growth analysis of sourgrass in field conditions, it is necessary to understand the factors contributing to the rapid dispersion of resistant biotypes within the crop. This may be related to continuous use of the selection pressure agent (herbicide), as well as to differential adaptive capacity between biotypes. This different adaptive capacity is called "fitness", which can be defined as the ability to leave fertile offspring for the next generation (Silvertown \& Charlesworth, 2001).

However, the number of viable seeds is directly related to the competitive ability of the biotypes. Thus, the cost of resistance can be measured as a reduction in the rate of growth and/or reproduction of the resistant biotype, when compared to the susceptible one (Newell, 2006). Some studies have shown a fitness cost associated with resistance of weeds to herbicides (Moreira, Melo, Carvalho, \& Christoffoleti, 2010). However, others have not shown any effect (Westhoven et al., 2008; Travlos \& Chachalis, 2013).

Evaluations of these differences between susceptible and resistant biotypes are fundamental to establish management strategies. Differences of adaptability may dictate management strategies aimed at reducing the density of resistant biotypes. Studies addressing the adaptive cost of sourgrass resistance to glyphosate are scarce. Martins, Barroso, and Alves (2017) have reported that seeds from resistant sourgrass biotypes germinate more in higher temperature ranges, water deficit and sowing depth than those from susceptible plants; thus, the full growth potential of susceptible and resistant biotypes needs to be clearly elucidated. It is necessary to understand if resistance to glyphosate reduces the biotype growth rate. This information is relevant to understand and define the competitive capacity between the biotypes and, therefore, contribute to the development of management strategies for this weed.

The objective of this work was to compare the growth rates of susceptible and resistant biotypes of sourgrass to glyphosate in a controlled environment and to describe the growth of the species in field conditions.

\section{Material and Methods}

Two experiments were conducted, one into greenhouse and other under field conditions, in the 2015/16 cropping season, both at Embrapa Soja, in Londrina-PR, Brazil.

Into the greenhouse, the experiment was installed on September 30, 2015, in completely randomized blocks design, in factorial scheme $2 \times 10$ (resistant and susceptible biotype $\times$ ten plant harvesting times), with eight replications. Experimental plots consisted of 160 plastic vases with volume of $500 \mathrm{~cm} 3$ filled with substrate, where 80 pots were seeded with glyphosate-resistant $D$. insularis biotypes and another 80 pots with the susceptible biotype, at approximate density of 12 seeds per vase, with subsequent thinning to 2 plants per vase.

The field experiment was installed in October 2015, in a soil containing $72 \%$ clay; $2.4 \%$ O.M.; $6.5 \mathrm{pH}\left(\mathrm{H}_{2} \mathrm{O}\right)$; $25.2 \mathrm{~g} \mathrm{~kg}^{-1} \mathrm{C} ; 7.5 \mathrm{mg} \mathrm{kg}{ }^{-1} \mathrm{P} ; 0.3 \mathrm{cmol} \mathrm{kg} \mathrm{K}^{+} ; 4.5 \mathrm{cmol} \mathrm{kg}{ }^{-1} \mathrm{Ca}^{2+} ; 0.5 \mathrm{cmol} \mathrm{kg} \mathrm{Mg}^{-1+} ; 0.0 \mathrm{cmol} \mathrm{kg}{ }^{-1} \mathrm{Al}^{3+} ; 4.0$ $\mathrm{cmol} \mathrm{kg} \mathrm{H}^{-1} \mathrm{H}^{+}+\mathrm{Al}^{3+} ; 5.51 \mathrm{cmol} \mathrm{kg}^{-1} \mathrm{CTC}$, in the completely randomized design, in factorial scheme with eight replications, with plots of $1.5 \times 3.0 \mathrm{~m}$. Plots were seeded with approximately 40 seeds $\mathrm{m}^{-2}$ of $D$. insularis, followed by light harrowing for seed incorporation.

In both experiments the evaluations were performed at 14 day intervals from plant emergence (DAE). In each evaluation the height of 16 plants per treatment was measured, selecting eight plants per treatment being randomly, which were harvested whole, also with the root system. Roots were washed in tap water for the removal of soil and impurities, after which the stem, leaves, roots and, after flowering, the panicles were separated. Each organ of the plants was placed in paper bags and taken to dry into forced air circulation oven at $70{ }^{\circ} \mathrm{C}$ until reaching constant weight. Subsequently the material was weighed in precision scale. Before drying, all the plants had their leaf area quantified by means of a photoelectric table meter, LI-COR brand, model 3100 .

The data set was submitted to analysis of variance by the F-test at $5 \%$ probability, being later explored by regression analysis with 95\% confidence intervals (Brighenti, Gazziero, Voll, Adegas, \& Vall, 2001). From the evaluated parameters, we opted for a functional approach for the growth analysis, being estimated the following parameters:

Relative Growth Rate $(\mathrm{RGR})=\mathrm{Ct} / \mathrm{DMt}$;

Net Assimilation Rate $(\mathrm{NAR})=\mathrm{Ct} / \mathrm{La}$;

Leaf Area Ratio $(\mathrm{LAR})=\mathrm{La} / \mathrm{DMt}$.

Where, $\mathrm{Ct}=$ dry mass; $\mathrm{DMt}=$ shoot dry mass; $\mathrm{La}=$ leaf area. 


\section{Results and Discussion}

\subsection{Greenhouse Experiment-Resistant Versus Susceptible}

The confidence intervals of the growth variables showed only mild and non-significant differences for plant height and dry mass of leaves and roots between biotypes (Figure 1). The resistant and the susceptible biotypes did not differ in their growth biometry at the experiment into controlled environment.

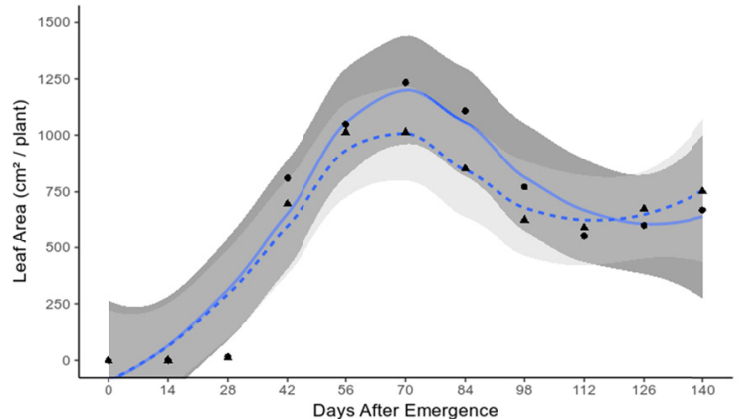

A

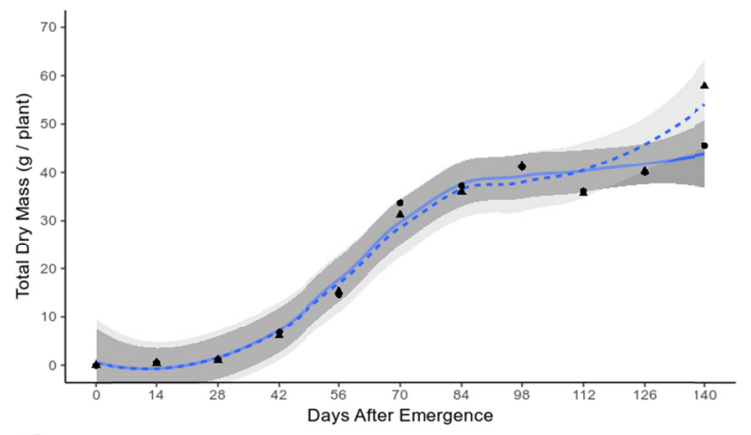

C

- Resistant $\downarrow$ suscepible

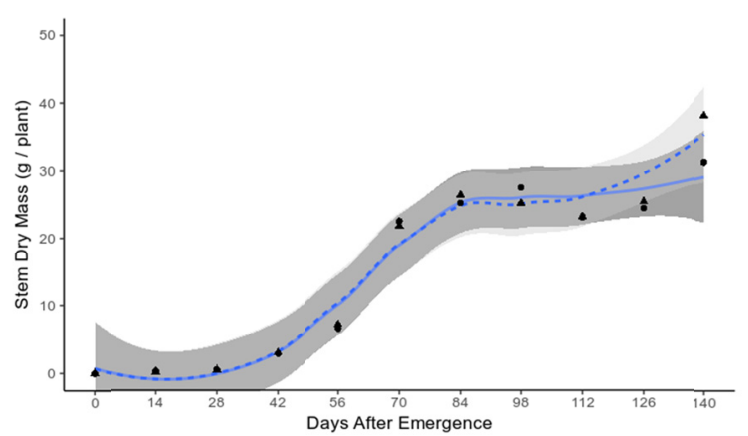

$E$
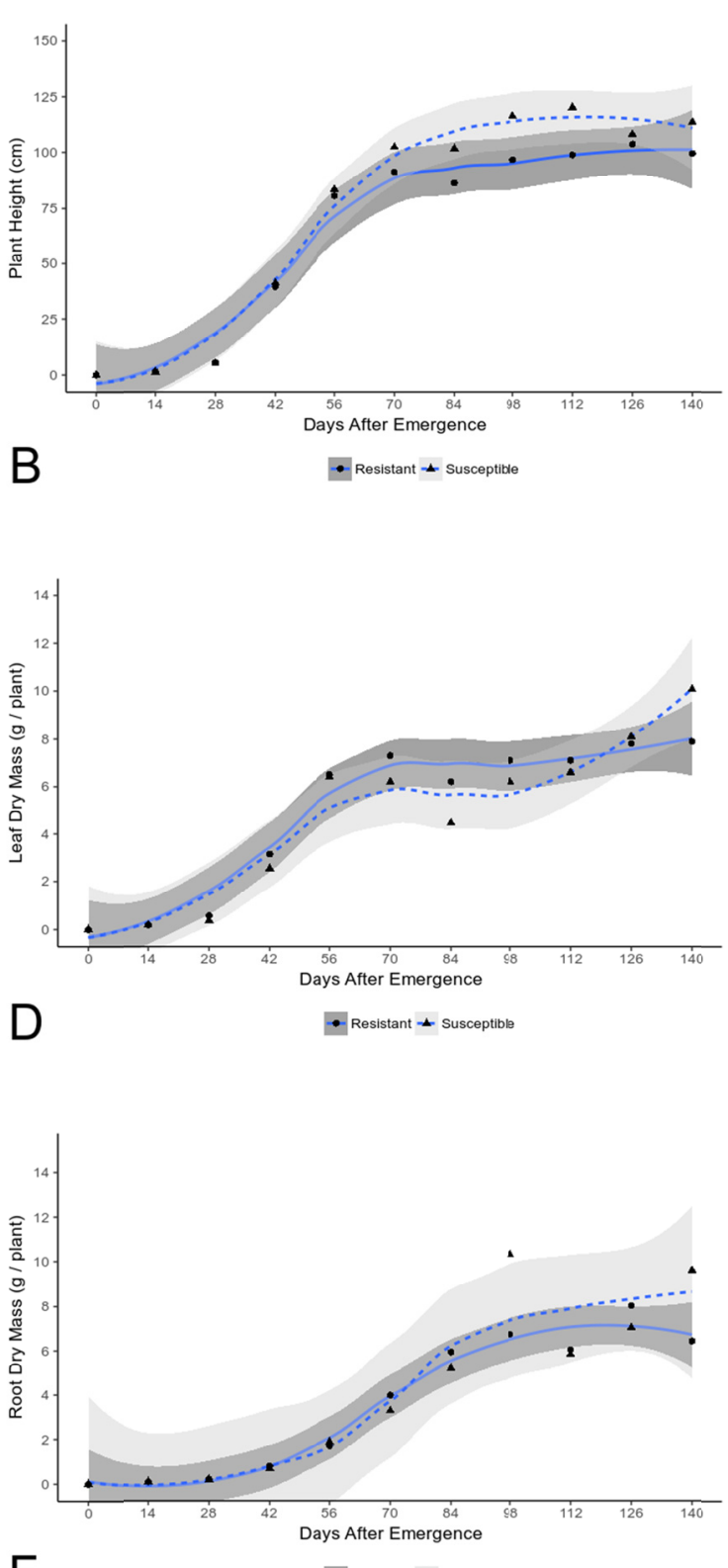

$\mathrm{F}$

- Resistant $\perp$ Susceptible

Figure 1. Evolution of leaf area (A), plant height (B), and total (C), leaf (D), shoot (E), and root (F) dry mass of sourgrass (Digitaria insularis) biotypes resistant and susceptible to glyphosate, under greenhouse. $2^{\text {nd }}$ degree

Loess regressions were adjusted to the data sets, with the respective $95 \%$ confidence intervals. Londrina, PR, 2016

The leaf area increased almost linearly from emergence, reaching a peak of about 70 DAE, with approximately $1000 \mathrm{~cm}^{2}$ plant $^{-1}$ of leaf area (Figure 1a); at this stage, under similar environmental and cultural conditions, it is expected for sourgrass plants to reach a peak in leaf are between 750 and $1350 \mathrm{~cm}^{2}$ plant $^{-1}$, according to the $95 \%$ 
confidence intervals, later decreasing in about $30 \%$ to the end of the plant cycle (Figure 1a). Most other variables (Figure 1) also tended to stabilization from about 70 DAE onwards. Plant height (Figure 1b) reached approximately $100 \mathrm{~cm}$ in height, while the dry mass of plants stabilized at about $35-52 \mathrm{~g} \mathrm{plant}^{-1}$ (Figure 1c). When the total dry mass of plants was divided for leaves (Figure 1d), stems (Figure 1e) and roots (Figure 1f), approximately $10-30 \% ; 40-90 \%$; and $10-30 \%$ of the total plant dry mass was attributed to each plant section, respectively, according to the $95 \%$ confidence intervals.

The similar behavior between resistant and susceptible biotypes of weeds to glyphosate has been verified by other authors. Vila-Aiub et al. (2014) observed that glyphosate-resistant Amaranthus palmeri biotypes, when compared to susceptible ones, did not present differences in growth parameters. However, divergent results demonstrate the superior adaptability (Kaspary et al., 2017) and lower (Shresta, Hanson, Fidelibus, \& Alcorta, 2010) for glyphosate resistant Conyza sp. biotypes, compared to the susceptible one. This, however, may often be attributed to methodological issues where differences between ecotypes are mistakenly attributed to biotypes, as highlighted by Concenço (2016). In general, there may be, or not, an adaptive cost related to the mechanisms of resistance (Cechin et al., 2017).

The maximum tiller formation occurred 70 DAE (data not shown). The similar stem dry mass of biotypes indicate equivalency in the number of tillers. Tillering capacity is preponderand in plant's ability of shade the area and occupy the available physical space aiming to maximize caption of environmental resources while interfering in the development of neighboring plants (Craine \& Dybzinski, 2013).

The onset of rhizome formation was observed $42 \mathrm{DAE}$, which resulted in a large increase in root dry mass as already reported. The recommendation for sourgrass control is performed so that the chemical control is carried out, preferably, before rhizome formation, since starch accumulation in these organs can reduce glyphosate translocation (Machado et al., 2008).

The relative growth rate (RGR) can be considered an efficient index of the plant, as it reflects the daily productive capacity of biomass per gram of plant biomass (Lopes \& Lima, 2015). The results indicate that the RGR remained stable until 56 DAE, with subsequent decrease to 84 DAE followed by its stabilization in about $0.05 \mathrm{~g} \mathrm{~g}^{-1}$ day $^{-1}$ (Figure 2a). This can be explained by the greater demand of photoassimilates in the phase of greater dry mass accumulation (Benincasa, 2003). The decrease in RGR as the plant ages is partially due to the gradual accumulation of non-assimilatory tissues (Lopes \& Lima, 2015).

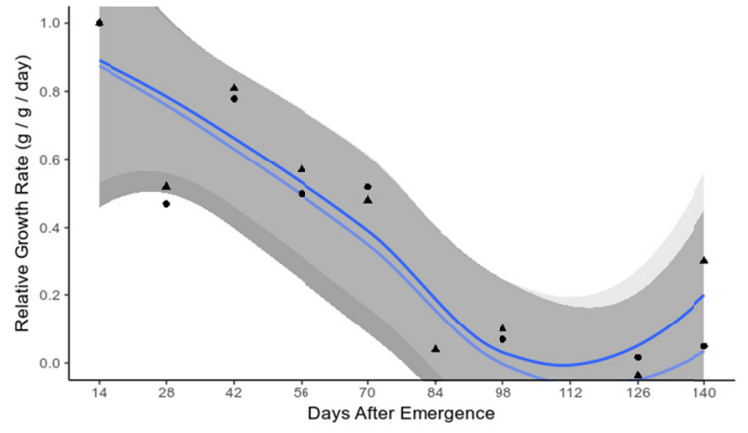

A

- Resistant 4 susceptible

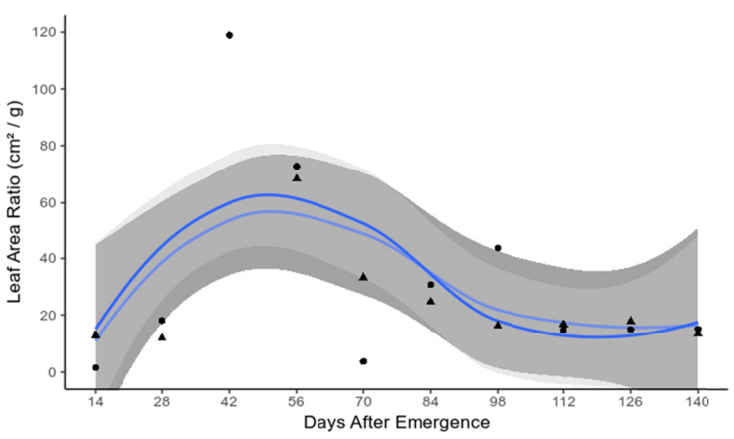

B

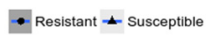




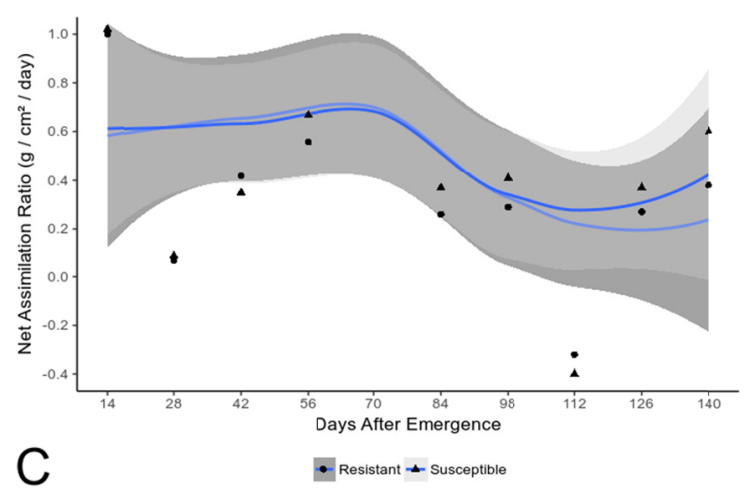

Figure 2. Relative growth rate (A), leaf area ratio (B) and net assimilation rate (C) of sourgrass (Digitaria insularis) biotypes, resistant and susceptible to glyphosate, under greenhouse. $2^{\text {nd }}$ degree Loess regressions were adjusted to the data sets, with the respective 95\% confidence intervals. Londrina, PR, 2016

With the development of sourgrass plants, there was a decrease in leaf area ratio (LAR), mainly from 70 DAE onwards (Figure 2b). This indicates decrease in photosynthetic plant apparatus in relation to the total dry mass. However, there were no changes in the net assimilation rate (NAR), showing that both biotypes had no changes in photosynthetic ability and rates during the experiment (Figure 2c). NAR is a measure of dry mass increase per unit of leaf area, evidencing the efficiency of the photosynthetic apparatus.

The behavior of the resistant and susceptible biotypes demonstrates that resistance to glyphosate is not correlated with a decrease in plant growth or development. The similarity between the growth variables and parameters indicates no differences in ecological adaptability and environmental niche occupation. In this way, preventive resistance management strategies must be adopted, because once a resistant population is established, it naturally does not return to an original higher susceptibility frequency of the susceptible biotype.

\subsection{Field Experiment-Growth Analysis}

Sourgrass showed slow initial growth up to 42 DAE. After this date, the plants showed a rapid increase in height to approximately $92 \mathrm{DAE}$ at which time their growth stabilized (Figure 3a). Leaf area accumulation occurred slowly up to $46 \mathrm{DAE}$ and after this period showed a large increase up to $74 \mathrm{DAE}$, during which flowering occurred (Figure 3b). Plants grown under field conditions (Figure 3), in general terms, had lower initial development compared to those grown under greenhouse conditions (Figure 1). This can be attributed mainly to the greater oscillation on environmental resources that directly interfere in plant growth. However, the values of these variables were close, with the maximum plant height of the plants reaching the average of $100 \mathrm{~cm}$ (Figure 3a), and maximum leaf area reaching $950 \mathrm{~cm}^{2}$ plant $^{-1}$ (Figure 3b). The period of stabilization in sourgrass growth matches with flowering, when plants tend to reduce the vegetative growth and store photo-assimilates to reproductive structures (Lopes \& Lima, 2015). 

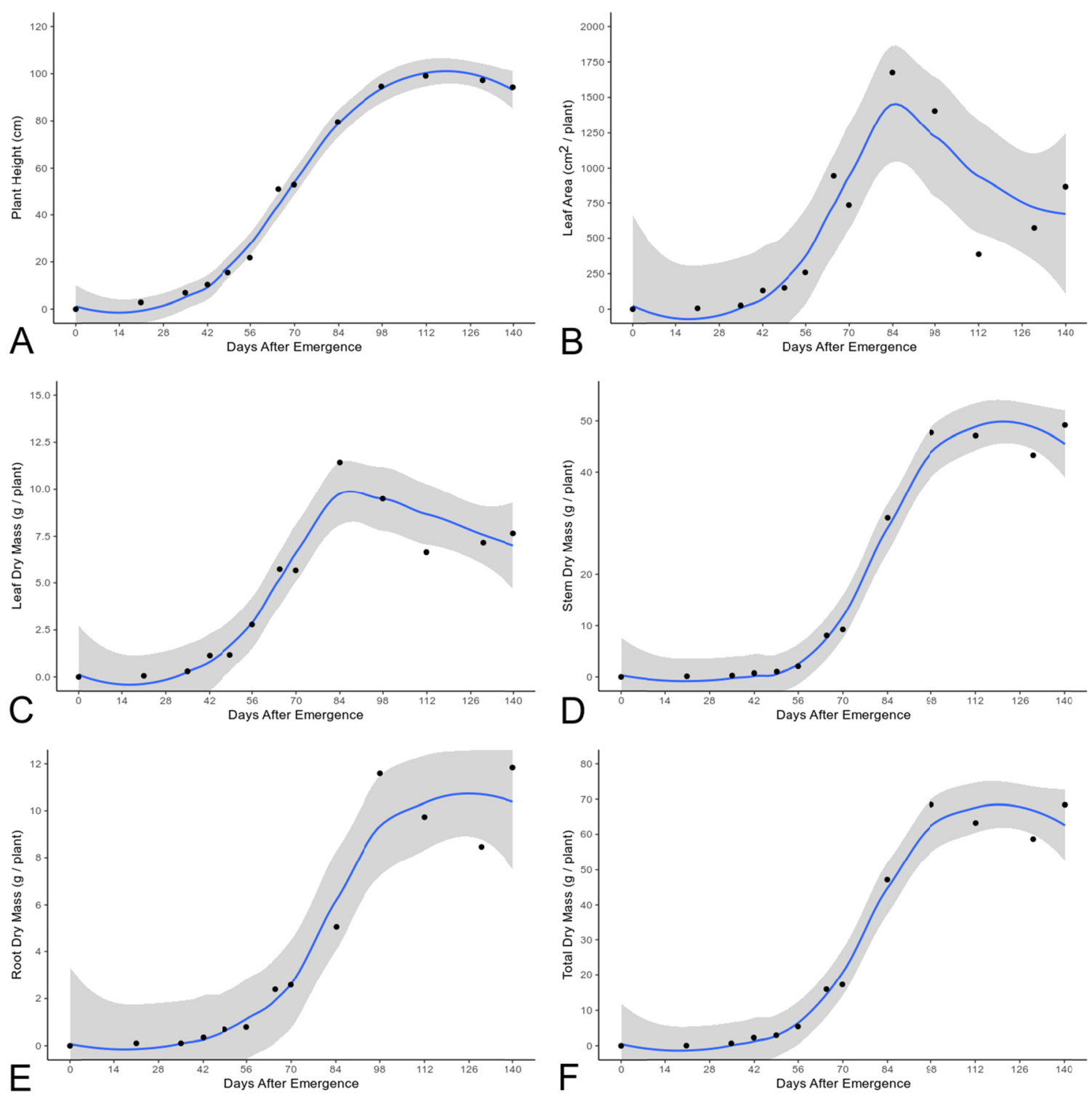

Figure 3. Evolution of plant height (A), leaf area (B), and leaf (C), stem (D), root (E) and total (F) dry mass of sourgrass (Digitaria insularis) under field conditions. $2^{\text {nd }}$ degree Loess regressions were adjusted to the data sets, with the respective 95\% confidence intervals. Londrina, PR, 2016

Dry mass accumulation in the field experiment (Figures 3c-3f) followed the same pattern of the reported for greenhouse (Figures 1c-1f). Maximum tillering was observed 70 DAE and rhizome formation started 42 DAE. Due to this, the total dry mass presented small accumulation rates up to $42 \mathrm{DAE}$, with high increasing rates 42-84 DAE, when its stabilization also occurred. The same was observed for the partitioned dry masses (Figures $3 \mathrm{c}-3 \mathrm{f})$. Cultural practices promoting rapid soil coverage by crops are important to reduce sourgrass interference potential on crop plants. Hammer, Stoltenberg, Colquoun, and Conley (2018), report that the genetic improvement of soybean, can contribute to competitiveness gain of the crop against weeds. However, this effect can be enhanced if associated to other cultural practices, such as adequate plant density, row spacing, planting time and fertilization rates.

The mean maximum plant dry mass weight (Figure 3f) was $69 \mathrm{~g} \mathrm{plant}^{-1}$, composed as the follows: $9.5 \mathrm{~g} \mathrm{plant}^{-1}$ of leaves (Figure 3c), $47.6 \mathrm{~g} \mathrm{plant}^{-1}$ of stems (Figure 3d), and $11.6 \mathrm{~g} \mathrm{plant}^{-1}$ of roots (Figure 3e); proportionally, about $69 \%$ stems, $17 \%$ roots and $13 \%$ leaves. The great proportion of dry mass attributed to stems shows the ability of this plant to grow and compete for light and physical space. 
The RGR obtained in the field (Figure 4a) were higher compared to those under greenhouse (Figure 2a), due to the higher dry mass accumulation mainly for stems (Figure 3d) and roots (Figure 3e). The limitation of physical space in pots used in greenhouse trials may negatively affect plant growth. However, in field there was also greater reductions in the RGR from 42 to 84 DAE (Figure 4a), similarly to the observed for the greenhouse experiment (Figure 2a). With the increase of dry mass accumulated by plants over time, there is an increase in the need for photo-assimilates to sustain already formed structures. In this way, the amount of energy available for its growth tends to be smaller and, consequently, its RGR decreases with time (Benincasa, 2003).
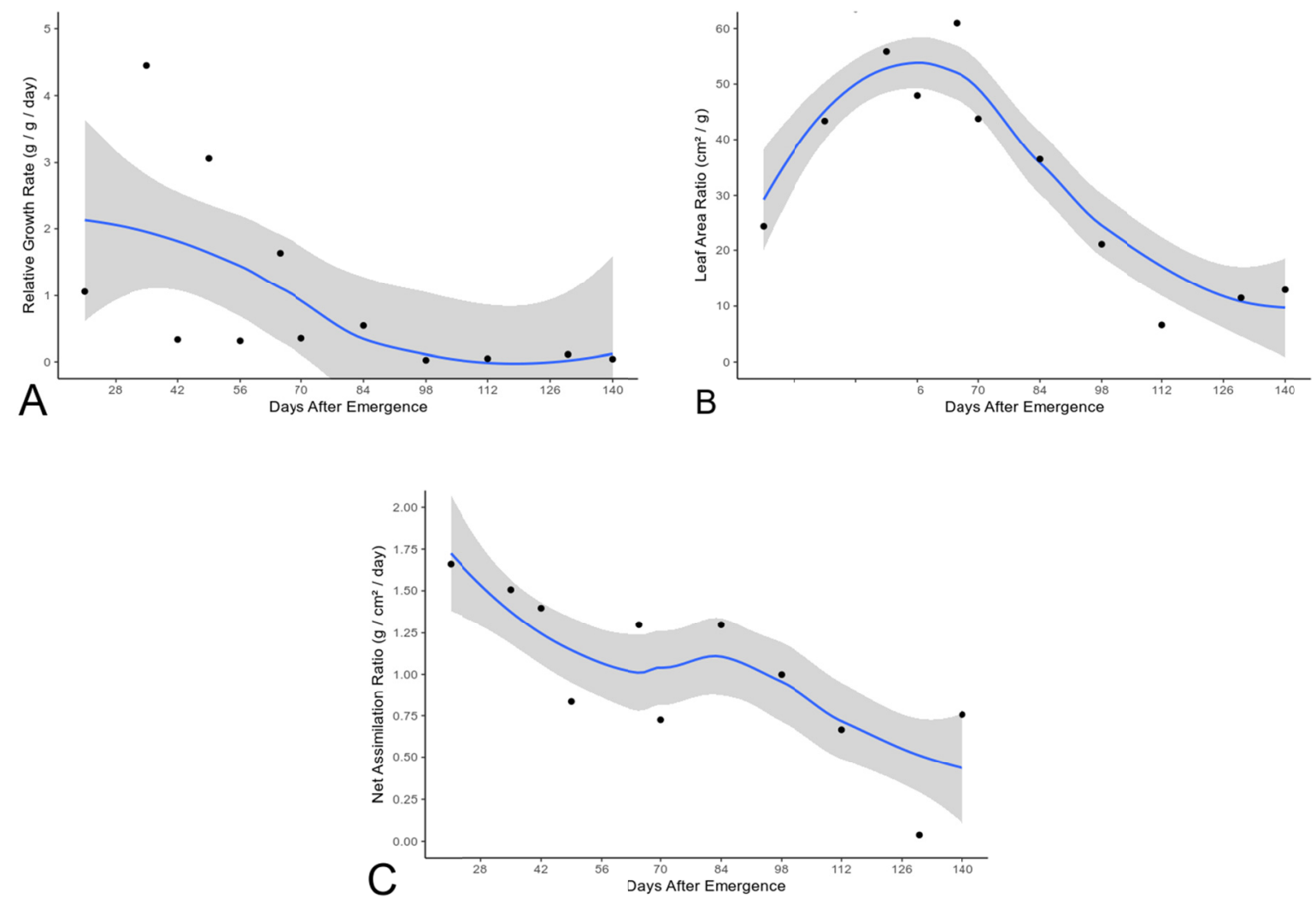

Figure 4. Relative growth rate (A), leaf area ratio (B) and net assimilation rate (C) of sourgrass (Digitaria insularis), under field conditions. $2^{\text {nd }}$ degree Loess regressions were adjusted to the data sets, with the respective 95\% confidence intervals. Londrina, PR, 2016

The decrease in LAR also showed a similar behavior (Figure 4b), with decrease reported from 70 DAE onwards. The net assimilation rate (NAR) was also similar for both experiment (Figures $2 \mathrm{c}$ and $4 \mathrm{c}$ ). The uniform behavior of NAR throughout the experiment duration demonstrates the great competitive capacity of this weed. However, these results differ from those by Machado et al. (2006), who reported decreasing in NAR of sourgrass over the evaluation period. This divergence may be related to genetic differences between ecotypes (Huangufu, Song, \& Qiang, 2009), as well as to differential abiotic factor levels such as temperature, luminosity, water and nutrients.

Similar trends are observed when comparing our sourgrass growth data with other studies performed under greenhouse, in general, being characterized by slow initial growth with subsequent exponential dry mass accumulation, followed by stabilization (Marques et al., 2014; C. M. Bianco \& S. Bianco, 2013; Machado et al., 2006). However, there are discrepancies regarding dry mass accumulation rates and plant development. The field experiment presented, mainly, a greater capacity of dry mass accumulation of stems and roots compared to the greenhouse trial (Carvalho et al., 2013; Machado et al., 2006). This was associated mainly to the limitation of physical space into the vases used as experimental plots.

Our results obtained resemble those obtained by Machado et al. (2006), who verified slow initial sougrass growth up to $45 \mathrm{DAE}$, rhizome formation and flowering, respectively, 45 and $98 \mathrm{DAE}$. However, Marques et al. 
(2013) and Carvalho et al. (2013) observed exponential increase in dry mass, respectively, from 70 and 50 DAE onwards, and flowering, respectively, 120 and 49 DAE. Variations between experiments are attributed to environmental conditions inherent to locality (temperature, luminosity), genetic variability among ecotypes, water and nutrient availability, and restrictions imposed on the development of the root system. Thus, although greenhouse trials portray the trend of growth behavior, they may underestimate sourgrass competitive ability.

The best period for sourgrass control is up to $42 \mathrm{DAE}$, when rhizomes have not yet been formed. Due to its slow initial growth, management strategies that promote rapid soil cover should be prioritized. However, due to the large increase rate in dry mass observed after this date, if the control is not performed sourgrass can become a dominant species due to its great dominance ability.

\section{Conclusions}

The biotype of sourgrass resistant to glyphosate do not present disadvantages in its growth/development compared to the susceptible one used as reference. In this way, it is necessary to prevent the entry of resistant biotypes in the area, because once established the area does not return naturally to the initial frequency susceptible plants.

Sourgrass has slow initial development and great increase in growth rates from 42 DAE onwards, which suggests that the control of this species should be performed preferably before this period.

\section{References}

Benincasa, M. M. P. (2003). Análise de crescimento de plantas, noções básicas (p. 41). Jaboticabal: FUNEP.

Brighenti, A. M., Gazziero, D. L. P., Vol, E., Adegas, F. S., \& Val, W. M. C. (2001). Análise de crescimento de biótipos de amendoim-bravo (Euphorbia heterophylla) resistente e suscetível a inibidores da ALS. Planta Daninha, 19(1), 51-59. https://doi.org/10.1590/S0100-83582001000100006

Carvalho, L. B., Bianco, M. S., \& Bianco, S. (2013). Acumulation of dry mass and macronutrients by sougrass plants. Planta Daninha, 31, 785-792. https://doi.org/10.1590/S0100-83582013000400004

Cechin, J., Vargas, L., Agostinetto, D., Zimmer, V., Pertile, M., \& Magro, T. D. (2017). Fiteness costs of susceptible and resistant radish biotypes to ALS-inibithor herbicides. Comunicata Scientiae, 8, 281-286. https://doi.org/10.14295/cs.v8i2.1877

Concenço, G. (2016). Evolution, epigenetics and resistance-troublesome weeds. Revista Brasileira de Herbicidas, 15, 14-25. https://doi.org/10.7824/rbh.v15i1.421

Craine, J. M., Dybzinski, R. (2013). Mechanisms of plant competition for nutrients, water and light. Functional Ecology, 27(4), 833-840. https://doi.org/10.1111/1365-2435.12081

Dewerff, R. P., Conley, S. P., Colquhoun, J. B., \& Davis, V. M. (2014). Can soybean seeding rate be used as an integrated componente of herbicide resistance management? Weed Science, 62, 625-636. https://doi.org/ 10.1614/WS-D-14-00047.1

Gemelli, A., Oliveira Jr, R., Constantin, J., Braz, G. B. P., Jumes, T. M. C., Neto, A. M. O., ... Biffe, D. F. (2013). Aspectos da biologia de Digitaria insularis resistente ao glyphosate e implicações para o seu controle Revista Brasileira de Herbicidas, 12, 162-170. https://doi.org/10.7824/rbh.v12i2.201

Gilo, E. G., Mendonça, C. G., Santo, T. L. E., \& Teodoro, P. E. (2016). Alternatives for chemical management of sourgrass Controle químico de capim-amargoso. Bioscience Journal, 32, 881-889. https://doi.org/ 10.14393/BJ-v32n4a2016-32786

Hammer, D. J., Stoltenberg, D. E., Colquoun, J. B., \& Conley, S. P. (2018). Has breeding improved soybean competitiveness with weeds? Weed Science, 66, 57-61. https://doi.org/10.1017/wsc.2017.60

Huangfu, C. H., Song, X. L., \& Qiang S. (2009). ISSR variation within and among wild Brassica juncea populations:implication for herbicide resistance evolution. Genetic Research Crop Evolution, 56, 913-924. https://doi.org/10.1007/s10722-009-9410-x

Kaspary, T. E., Lamego, F. P., Cutti, L., Aguiar, A. C. M., Rigon, C. A. G., \& Basso, C. J. (2017) Growth, phenology, and seed viability between glyphosate-resistant and glyphosate-suscetible hair flabane. Bragantia, 76, 92-101. https://doi.org/10.1590/1678-4499.542

Lopes, N. F., \& Lima, M. G. S. (2015). Physiology of Crop Production (p. 492). Viçosa: UFV. 
Machado, A. F. L., Ferreira, L. R., Ferreira, F. A., Fialho, C. M. T., Tuffi, S. L. D., \& Machado, M. S. (2006). Análise de crescimento de Digitaria insularis. Planta Daninha, 24, 641-647. https://doi.org/10.1590/ S0100-83582006000400004

Machado, A. F. L., Meira, R. M. S., Ferreira, L. R., Ferreira, F. A., Tuffi, S. L. D., Fialho, C. M. T., \& Machado, M. S. (2008). Caracterização anatômica de folha, colmo e rizoma de Digitaria insularis. Planta Daninha, 26, 1-8. https://doi.org/10.1590/S0100-83582008000100001

Marques, B. S., Silva, A. P. P., Lima, R. S. O., Machado, E. C. R., Gonçalves, M. F., \& Carvalho, S. J. P. (2014). Growth and development of sourgrass based on days or termal units. Planta Daninha, 32, 483-490. https://doi.org/10.1590/S0100-83582014000300003

Martins, J. F., Barroso, A. A. M., \& Alves, P. L. C. A. (2017). Efects of enviromental factors on seed germination and emergence of glyphosate resistant and susceptibible sourgrass. Planta Daninha, 35, e017164499. https://doi.org/10.1590/s0100-83582017350100039

Mendonça S. G., Martins C. C., Martins D., \& Costa V. N. (2014). Ecofisiologia da germinação de sementes de Digitaria insularis (L.) Fedde. Revista Ciência Agronômica, 45(4), 823-832. https://doi.org/10.1590/ S1806-66902014000400021

Moreira, M. S., Melo, M. S. C., Carvalho, S. J. P., \& Christoffoleti, P. J. (2010). Crescimento diferencial de biótipos de Conyza spp. resistente e suscetível ao herbicida glifosato. Bragantia, 69, 591-598. https://doi.org/10.1590/S0006-87052010000300010

Newell, S. J. (2006). Does herbicide resistance have a cost in Brassica rapa? The american Biology Teacher, 68 , 530-535. https://doi.org/10.1662/0002-7685(2006)68[530:DHRHAC]2.0.CO;2

Ovejerp, R. F. L., Takano, H. K., Nicolai, M., Ferreira, A., Melo, M. S., Cavenaghi, A. L., \& Oliveira Jr, R. S. (2017). Frequency and Dispersal of Glyphosate-Resistant Sourgrass (Digitaria insularis) Populations across Brazilian Agricultural Production Areas. Weed Science, 65, 285-294. https://doi.org/10.1017/wsc.2016.31

Shrestha, A., Hanson, B. D., Fidelibus, M. W., \& Alcorta, M. (2010). Growth, Phenology, and Intraspecific Competition between Glyphosate-Resistant and Glyphosate-Susceptible Horseweeds (Conyza canadensis) in the San Joaquin Valley of California. Weed Science, 58, 147-153. https://doi.org/10.1614/ WS-D-09-00022.1

Silvertown, J. W., \& Charlesworth, D. (2001). Introduction to Plant Population Biology (4th ed.). Oxford: Blackwell Science.

Travlos, I. S., \& Chachalis, D. (2013). Relative competitiveness of glyphosate-resistant and glyphosate susceptible populations of hairy fleabane, Conyza bonariensis. Journal of Pest Science, 86, 345-351. https://doi.org/10.1007/s10340-012-0446-x

Vila-Aiub, M. M., Goh, S. S., Gaines, T. A., Han, H., Busi, R., Yu, Q., \& Powles, S. B. (2014). No fitness cost of glyphosate resistance endowed by massive EPSPs gene amplification in Amaranthus palmeri. Planta, 4, 793-801. https://doi.org/10.1007/s00425-013-2022-x

Wells, M. S., Reberg-Horton, C., \& Mirsky, S. B. (2014). Cultural Strategies for managing weeds and soil moisture in cover crop based no-till soybean production. Weed Science, 62, 501-11. https://doi.org/ 10.1614/WS-D-13-00142.1

Westhoven, A. M., Kruger, G. R., Gerber, C. K., Stachler, J. M., Loux, M. M., \& Johnson, W. G. (2008). Characterization of selected common lambsquarters (Chenopodium album) biotypes with tolerance to glyphosate. Weed Science, 56, 685-691. https://doi.org/10.1614/WS-08-018.1

\section{Copyrights}

Copyright for this article is retained by the author(s), with first publication rights granted to the journal.

This is an open-access article distributed under the terms and conditions of the Creative Commons Attribution license (http://creativecommons.org/licenses/by/4.0/). 